DOI: $10.19195 / 2084-5065.50 .11$

\title{
„Readaptacja społeczna w świetle uwarunkowań prawnych i psychologicznych"
}

\author{
EDYTA ŻEGLEŃ-NYCZ \\ ORCID: 0000-0002-0339-1487 \\ Sąd Rejonowy w Nowym Targu
}

W dniach 17-19 października 2018 roku w Krynicy-Zdroju odbyła się konferencja poświęcona problemom readaptacji społecznej w świetle uwarunkowań prawnych i psychologicznych. Była to już czwarta konferencja zorganizowana przy współpracy Sądu Okręgowego w Nowym Sączu, Okręgowego Inspektoratu Służby Więziennej w Krakowie, Stowarzyszenia Sursum Corda oraz Krakowskiego Stowarzyszenia Kuratorów Sądowych. Odbyła się ona pod honorowym patronatem Burmistrza Krynicy-Zdrój, Prezesa Sądu Okręgowego w Nowym Sączu oraz Dyrektora Okręgowego Służby Więziennej w Krakowie.

Poprzednie konferencje miały miejsce w latach 2015-2017 również w Krynicy-Zdroju. Ich głównym inicjatorem był Zastępca Kuratora Okręgowego w Nowym Sączu Krzysztof Jasiński. W trakcie konferencji w roku 2015 po raz pierwszy w Polsce spotkały się podmioty biorące udział w pomocy postpenitencjarnej, to jest organizacje pozarządowe oraz służby i instytucje, aby kontynuować i rozwijać wzajemną współpracę. Konferencja ta zakończyła się podpisaniem porozumień i przyjęciem rekomendacji.

W roku 2016 odbyła się następna konferencja, zatytułowana „Resocjalizacja, readaptacja i pomoc postpenitencjarna w kontekście uwa- 
runkowań prawnych systemowych i lokalnych”. Wśród jej uczestników znaleźli się między innymi: Anna Andrzejewska - Pełnomocnik Ministra Sprawiedliwości ds. Konstytucyjnych Praw Rodziny i Zastępca Dyrektora Departamentu Spraw Rodzinnych i Nieletnich, która była obecna na pierwszej konferencji w 2015 roku, gen. Paweł Nasiłowski - Pełnomocnik Ministra Sprawiedliwości ds. Kar Nieizolacyjnych i Wdrożenia Systemu Dozoru Elektronicznego i Dyrektor Biura Dozoru Elektronicznego w Centralnym Zarządzie Służby Więziennej, Barbara Wilamowska - Koordynator Ministra Sprawiedliwości ds. Przeciwdziałania Narkomanii i Koordynator Działań Kuratorskiej Służby Sądowej w Systemie Dozoru Elektronicznego, dr hab. Barbara Nowak, prof. Uniwersytetu Pedagogicznego w Krakowie, i dr hab. Barbara Stańdo-Kawecka, prof. Uniwersytetu Jagiellońskiego w Krakowie. Podczas tej konferencji zdiagnozowano problemy związane $\mathrm{z}$ resocjalizacją, readaptacją i pomocą postpenitencjarną oraz zaprezentowano po raz pierwszy tworzony przez Zastępcę Kuratora Okręgowego Krzysztofa Jasińskiego i kuratorów sądowych portal „I co dalej.info”.

Tematem kolejnej konferencji, która odbyła się w roku 2017, było „Wsparcie readaptacyjne w prewencji wykluczenia i recydywy”. Ponownie spotkali się na niej przedstawiciele świata nauki oraz praktycy w dziedzinie resocjalizacji, między innymi sędziowie, kuratorzy, pracownicy Służby Więziennej, przedstawiciele organizacji pozarządowych $\mathrm{z}$ kraju i zagranicy. Podczas konferencji uwagę skupiono na zwiększeniu spójności działań podejmowanych przez różne podmioty biorące udział w procesie readaptacji, aby przez to zwiększyć efektywność pracy. Podkreślono, że oddziaływania prowadzone w jednostkach penitencjarnych i ich kontynuacja na wolności ze skazanymi opuszczającymi te jednostki prowadzi do ograniczenia powrotności do przestępstwa.

W tegorocznej konferencji „Readaptacja społeczna w świetle uwarunkowań prawnych i psychologicznych" wzięli udział między innymi pracownicy naukowi, sędziowie, kuratorzy, pracownicy Służby Więziennej oraz referenci zagraniczni. Została ona otwarta wystąpieniami Burmistrza Krynicy-Zdroju dr Dariusza Reśko, Prezesa Sądu Okręgowego w Nowym Sączu Zbigniewa Krupy, Marcina Kałużnego ze Stowarzyszenia Sursum Corda z Nowego Sącza, Dyrektora Okręgowego Służby Więziennej w Krakowie ppłk. Włodzimierza Więckowskiego oraz 
Prezesa Krakowskiego Stowarzyszenia Kuratorów Sądowych Dariusza Palmirskiego.

Konferencja trwała trzy dni i składała się z kilku paneli. W pierwszym dniu odbyły się dwie części panelu naukowo-prawnego, w których wzięli udział przedstawiciele świata nauki z kraju i z zagranicy oraz sędziowie. Pierwszy panel rozpoczął referat na temat przestępczości młodzieży na Słowacji, wypowiedziała się przedstawicielka Uniwersytetu Komeńskiego w Bratysławie prof. Monika Mackinova (PhD., Katedra Pracy Socjalnej, Wydział Pedagogiczny) w referacie Regionalna specyfika przestępczości młodzieży. Referentka zwróciła uwagę, jak duży nacisk powinien być położony na czynniki wpływające na przestępczość młodzieży — poznanie ich i wyeliminowanie pozwoli zapobiegać jej w przyszłości poprzez działania prewencyjne. W kolejnym wystąpieniu pt. Praca socjalna z bezrobotnymi, ze szczególnym uwzględnieniem zwalnianych z zakładu karnego Jan Holonic (PhD., Katedra Pracy Socjalnej, Wydział Pedagogiczny), również z Uniwersytetu Komeńskiego w Bratysławie poruszył kwestie związane z readaptacją społeczną, w której jego zdaniem kluczową rolę odgrywa pracownik socjalny zajmujący się skazanym w zakładzie karnym, a następnie po opuszczeniu zakładu karnego. Pracownik ten musi współpracować z kuratorem i instytucjami, ponieważ sam nie jest w stanie wszystkiego dokonać w procesie readaptacji. Następny referat pt. Przygotowanie skazanego do zwolnienia z zakładu karnego wygłosił JUdr. PhDr. Ing. Stefan Nezsmery (LL.M., Katedra Pracy Socjalnej, Wydział Pedagogiczny) jako kolejny reprezentant Uniwersytetu Komeńskiego w Bratysławie. Na podstawie omówionego przypadku osoby skazanej, która podczas odbywania kary straciła rodzinę, pracę, miejsce zamieszkania, pokazał, jak ważne jest zapewnienie pomocy opuszczającym zakłady karne, aby ponownie nie trafili na drogę przestępczą. Podsumowując swoje wystąpienie, dodał, że skazany powinien być przygotowywany podczas odbywania kary do tego, co czeka go na wolności i otrzymać pomoc. Jako kolejny referent wypowiedział się przedstawiciel Uniwersytetu Łódzkiego prof. zw. dr hab. Stefan Lelental (Zakład Prawa Karnego Wykonawczego, Katedra Prawa Karnego Międzynarodowego) w referacie pt. Charakter prawny umieszczenia skazanego w Krajowym Ośrodku Zapobiegania Zachowaniom Dyssocjalnym w Gostyninie, po odbyciu kary pozbawienia wolności. Zwrócił on uwagę 
na funkcjonowanie ustawy w praktyce, omawiając pojawiające się wątpliwości oraz przesłanki zastosowania. Poruszył także kwestie związane z rozumieniem orzeczenia o umieszczeniu w ośrodku. Podsumowując referat, dodał, że zaczyna to być zjawiskiem znaczącym, ponieważ liczba umieszczanych tam osób wciąż rośnie i konieczne jest wyciągniecie z tego wniosków. Następne wystąpienie należało do dr hab. Barbary Stańdo-Kaweckiej, prof. Uniwersytetu Jagiellońskiego (Zakład Prawa Karnego Wykonawczego). W referacie Paradygmaty karania a badania osobopoznawcze sprawców przestępstw wskazała, że w peneologii można ostatnio zauważyć podejście określane jako integralno-kulturowe, które zakłada potrzebę integracji dorobku różnych nauk w celu uzyskania ujednoliconego obrazu kary, widzianego z perspektywy różnych nauk. Sama potrzeba integrowania wiedzy na temat kary, postrzegania kary z różnych perspektyw jest potrzebna, ale prelegentka wyraziła obawę, że taka integracja wiedzy jest dość złożonym problemem. Na podejście do kary i karania wpływa również ogromna ilość czynników lokalnych i globalnych. Zatem podejście do karania jest złożone i zmienne w czasie. Poleciła zastanowić się, czy istnieje spójny sposób patrzenia na przestępczość, przyczyny kary i system karania. Podsumowując swoje wystąpienie, wskazała, że w dzisiejszym zachodnim świecie oraz w Polsce obserwuje się chaos w polityce kryminalnej, są fragmentaryczne reformy, które nie są kompatybilne z całością przepisów prawnych, czasami są motywowane doraźnymi interesami politycznymi ze względu na presję społeczną wywieraną na politykach. W związku z tym pojawiają się doraźne rozwiązania, które po jakimś czasie są uchylane, istnieje więc ogromna zmienność w polityce kryminalnej. Omówiła pojawiające się tendencje strategii menadżerskich w procesie readaptacji. Według referentki ważne jest rozdzielenie środków przeznaczonych na zapobieganie przestępczości według wypracowanych kryteriów opartych na ustalonym stanie wiedzy. Ostatnie wystąpienie poświęcone było Naukowym podstawom innowacyjnych rozwiazań readaptacyjnych - Employment Bridge to the Future. Doktor Joanna Chwaszcz z Katolickiego Uniwersytetu Lubelskiego im. Jana Pawła II (Instytut Psychologii, Katedra Psychoprofilaktyki Społecznej) omówiła trzy filary czynników warunkujących skuteczność oddziaływań resocjalizacyjnych i readaptacyjnych, jakie wypracowano w zespole, w którym pracuje. Pierwszy to rozumienie pro- 
cesu resocjalizacji i readaptacji oraz ograniczeń związanych z badaniem ich skuteczności. Drugi to oparcie resocjalizacji i readaptacji na wiedzy naukowej w zakresie czynników zmian w zakresie resocjalizacji i readaptacji. Trzeci to oparcie interwencji resocjalizacyjnych i readaptacyjnych na wiedzy naukowej w zakresie o sprawdzonej skuteczności. Zespół sporządził też narzędzia do pracy z osadzonymi i byłymi osadzonymi, które dopasowane są nie tylko do nich, lecz także do osób, które z nimi pracują. Jako główne narzędzie wspierające dla osób pracujących z osadzonymi i byłymi osadzonymi wskazana została superwizja. Metody wypracowane w ramach zespołu są stosowne w zakładach karnych.

Część drugą panelu naukowo-prawnego rozpoczął referat dotyczący systemu dozoru elektronicznego. Pod nieobecność gen. Pawła Nasiłowskiego, Pełnomocnika Ministra Sprawiedliwości ds. Kar Nieizolacyjnych i Wdrożenia Systemu Dozoru Elektronicznego, wygłosiła Barbara Wilamowska (Prezes Małopolskiego Stowarzyszenia Probacja w Krakowie). Referentka przedstawiła rys historyczny powstawania systemu dozoru elektronicznego w Polsce, omawiając kolejne nowelizacje przepisów dotyczących tej instytucji i wkomponowania jej w system prawa karnego. Zakończony został etap współpracy z dotychczasowym wykonawcą i rozpoczął się nowy etap rozwoju systemu dozoru elektronicznego. Obecnie zadania podmiotu dozorującego zostały powierzone służbie więziennej. Nastąpiła zmiana systemu. Jednostki terenowe zostały rozlokowane przy jednostkach penitencjarnych. Prezes Wilamowska zaprezentowała nowe urządzenia systemu dozoru elektronicznego. Kolejny referat $L e ̨ k$ przed wolnościa w kontekście niezaradności życiowej osadzonych kobiet wygłosiła dr hab. Barbara Nowak, prof. Uniwersytetu Pedagogicznego w Krakowie (Instytut Pracy Socjalnej, Katedra Pomocy Postpenitencjarnej i Wychowania do Pracy). W trakcie swojego wystąpienia nawiązała do arkusza prognostycznego zaradności życiowej, który zaprezentowała na poprzedniej konferencji. Jak wynika z przedstawionego wycinka badań, czas oczekiwania na wyjście na wolność naznaczony jest wśród kobiet lękiem spowodowanym doświadczeniami życiowymi na wolności. Osadzone często zadają pytanie „Jak sobie poradzę na wolności?”. Przygotowanie do powrotu na wolność skupia się na przełamywaniu lęków oraz wzbudzeniu przekonania, że są w stanie sobie poradzić. Zdaniem referentki lęki zależą od układu wielu czynników. Jak wykazały badania, są 
to między innymi brak pieniędzy, doświadczenia z dzieciństwa, doświadczenia edukacyjne, brak modnej odzieży, przeżycia rodzinne, brak pracy, doświadczenia przemocowe. Eliminacja lęków w trakcie odbywania kary pozwoli na inne postrzeganie oczekiwania na wyjście na wolność. Kolejny referat pt. Środki zabezpieczajace w polskim prawie karnym przedstawiła dr Magdalena Niewiadomska-Krawczyk z Uniwersytetu Łódzkiego (Katedra Prawa Karnego Międzynarodowego, Zakład Międzynarodowego Wymiaru Sprawiedliwości). Omówiła ona źródła i genezę oraz istotę środków zabezpieczających. Dokonała porównania modeli środków zabezpieczających do mementu nowelizacji w lipcu 2015 roku oraz modelu obowiązującego po tej dacie. Wskazała na zasady stosowania środków zabezpieczających w obecnym modelu. Kompleksowo i merytorycznie przedstawiła kwestie dotyczące środków zabezpieczających. Doktor hab. Barbara Nowak, prof. z Uniwersytetu Pedagogicznego w Krakowie (Instytut Pracy Socjalnej, Katedra Pomocy Postpenitencjarnej i Wychowania do Pracy), w referacie Przestrzeń Kultury jako czynnik przygotowujący do życia wolnościowego w opinii skazanych przedstawiła wyniki przeprowadzonych przez siebie badań dotyczących zajęć kulturalno-oświatowych. Podkreśliła przy tym, jak ważną rolę odgrywają te zajęcia w przygotowaniu do życia wolnościowego. W ramach badań były między innymi prowadzone zajęcia z przestrzeni kultury — matki i dziecka. Zajęcia te miały duży wpływ na zawiązanie się silnej więzi, dziedzictwo kulturowe zostało uczynione przedmiotem działania wspólnego. Zajęcia pomagały w budowaniu relacji i współdziałania, spowodowały zminimalizowanie lęku przed życiem na wolności. Obszar kultury dał nadzieję na sprostanie życiu na wolności. Ostatni referat panelu Ustawa z 22 listopada 2013 roku o postępowaniu wobec osób z zaburzeniami psychicznymi stwarzającymi zagrożenie życia, zdrowia lub wolności seksualnej innych osób-od problemów konstytucyjnych do wattpliwości proceduralnych na podstawie studium przypadku został przedstawiony przez jednego z praktyków sędziów Sądu Okręgowego w Nowym Sączu. Sędzia Sądu Okręgowego w stanie spoczynku Jacek Gacek omówił na wybranym przykładzie problemy pojawiające się w związku z rozstrzyganiem tego rodzaju spraw oraz zobrazował powód, dla którego pobyt w Krajowym Ośrodku Zapobiegania Zachowaniom Dyssocjalnym w Gostyninie stał się czymś dość powszechnym w polskim wymiarze sprawiedliwości. 
Następnie razem z przewodniczącym II Wydziału Karnego Sądu Okręgowego w Nowym Sączu, sędzią Sądu Okręgowego Pawłem Gnutkiem, w swoich wypowiedziach odnieśli się do reformy wymiaru sprawiedliwości w kontekście problemów konstytucyjnych co do wątpliwości proceduralnych. Podsumowując swoje wystąpienie, zapewnili, że stoją na straży prawa i realizacji zasady, że każdy może liczyć na sprawiedliwy proces.

Pierwsza część panelu naukowo-prawnego pokazała spójność teorii i praktyki resocjalizacyjnej i readaptacyjnej oraz konieczność korzystania z dorobku nauk kryminologicznych, pedagogicznych i prawnych dla realizacji praktycznych celów readaptacji społecznej skazanych. Natomiast w drugiej części podkreślono, jakie obawy i lęki przeżywają osoby opuszczające zakłady karne i jakie znaczenie ma już na tym etapie udzielenie im pomocy przed opuszczeniem zakładu karnego. Kolejne wystąpienia potwierdziły, jak cenne jest zaangażowanie się w pomoc poprzez różne programy realizowane zarówno przez służbę więzienną, jak i organizacje pozarządowe, które pozwolą przygotować skazanych do życia na wolności.

W drugim dniu konferencji odbył się kolejny panel dotyczący psychospołecznych determinantów skutecznej readaptacji. W jego trakcie zabrali głos praktycy, a ich spostrzeżenia poparte zostały wystąpieniami naukowców. Pierwszym referentem była dr Gertruda Wieczorek z Uniwersytetu Pedagogicznego w Krakowie (Instytut Pracy Socjalnej, Katedra Pomocy Postpenitencjarnej i Wychowania do Pracy). Zwróciła uwagę na niski poziom wiedzy społecznej na temat wykonywania kar. Społeczeństwo wie na ten temat tyle, ile przekażą media, brakuje programów edukacyjnych na temat odbywania kary w zakładach karnych. Przedstawiła projekt badań pilotażowych prowadzonych w tym zakresie, które to potwierdzily. Podsumowując swój referat, podkreśliła, że należałoby zwrócić uwagę na edukację oraz uświadomienie społeczeństwa poprzez pokazanie działań podejmowanych przez podmioty biorące udział w readaptacji skazanych. Kolejne wystąpienia należały do przedstawicieli organizacji pozarządowych oraz funkcjonariuszy Służby Więziennej i odnosiły się do pozasystemowych działań wobec osób opuszczających zakłady karne oraz determinantów readaptacji skazanych z różnymi zaburzeniami. Ksiądz Mieczysław Puzewicz (Centrum Wolontariatu w Lublinie, Członek prezydium Rady 
Głównej ds. Społecznej Readaptacji i Pomocy Skazanym, Delegat Biskupi ds. Osób Wykluczonych Społecznie) w wystąpieniu Pozasystemowe czynniki skutecznej readaptacji osób opuszczających zakłady karne podzielił się doświadczeniami w pracy z osobami opuszczającymi zakłady karne. $Z$ przedstawionego referatu można było wyciągnąć wnioski, że nawet najlepsze programy nie zastąpią relacji międzyludzkich w oddziaływaniach readaptacyjnych. Wyrazem tego jest realizowany projekt „Nowa Droga”. Kolejne wystąpienie pt. Znaczenie treningu społeczno-psychologicznego $w$ opiece penitencjarnej i postpenitencjarnej wygłosiła dr Martina Spanikova ze słowackiej organizacji „Edukos” (Katolicki Uniwersytet w Rużomberoku, Dolny Kubin). Omówiła prowadzone przez „Edukos” treningi społeczno-psychologiczne. We wnioskach wskazała, że treningi pomagają w życiu na wolności. Podsumowując swoje wystąpienie, dodała, że aby readaptacja była skuteczna, osadzeni muszą być przygotowani do życia na wolności. Pomocna w tym zakresie okazała się gra, za pomocą której można nabyć wszelkie umiejętności potrzebne na wolności. Z kolei mjr Anna Pyszniak-Zarzycka (kierownik Oddziału Terapeutycznego dla skazanych z niepsychotycznymi zaburzeniami psychicznymi, Areszt Śledczy w Kielcach) przestawiła trudy pracy z osadzonymi z niepsychotycznymi zaburzeniami psychicznymi. Podkreśliła, jak ważna jest praca człowieka $z$ drugim człowiekiem i zrozumienie popełnionego czynu z perspektywy tej osoby. Referat wygłoszony przez Katarzynę Jakubas (młodszy psycholog, Zakład Karny Rzeszów-Załęże) — Oddziaływania terapeutyczne stosowane wobec sprawców przestępstw seksualnych jako szansa na skuteczna readaptacje — unaocznił, jak ważne jest poznanie czynników, które doprowadziły do popełnienia przestępstwa. Zidentyfikowanie tych czynników przez osadzonego pozwoli mu w życiu na wolności powstrzymać się od popełnienia przestępstwa. Ostatnie wystąpienie w tym panelu - Opinie więźniów o przestępczej motywacji i karze w kontekście pytania o praktyczne zastosowanie teorii neutralizacji w oddziałach terapeutycznych — należało do dr. Roberta Frei (Instytut Socjologii, Zakład Socjologii Stosowanej i Pracy Socjalnej, Uniwersytet Wrocławski). Wskazał on, że zwiększenie poczucia identyfikacji osadzonego z jego czynem ma kluczowe znaczenie. Następny panel $\mathrm{w}$ drugim dniu konferencji został poświęcony małoletnim, nieletnim i młodocianym w procesie resocjalizacji. Doktor Justyna Kusztal (Instytut Pedagogiki, Zakład Pedagogiki Szkolnej i Dydaktyki Akademickiej, Uni- 
wersytet Jagielloński) przedstawiła prezentację na temat Nieletni i eksperci o procesie resocjalizacji — rezultaty terenowych badań jakościowych metoda zogniskowanego wywiadu grupowego $i$ wywiadów indywidualnych. Podkreśliła, że wyniki badań pokazały napięcia pomiędzy podmiotami procesu resocjalizacji a sferą normatywną oraz zasadami resocjalizacji a sferą normatywną. Jak wykazała, resocjalizacja potrzebuje prawa, aby prawa dziecka nie zostały naruszone. Natomiast pedagodzy resocjalizacyjni biorący udział w badaniu podkreślili, że prawo ich krępuje. Prezentowane wyniki badań pokazały, jak zróżnicowany jest obraz resocjalizacji i jak rozbieżne jest do niej podejście. Kolejne wystąpienie zatytułowane Ochrona dziecka - ofiary przestępstwa przed wtórna wiktymizacja aspekty procesowe i psychologiczno-pedagogiczne należało do dr Małgorzaty Turczyk (Instytut Pedagogiki, Zakład Pedagogiki Szkolnej i Dydaktyki Akademickiej, Uniwersytet Jagielloński). W jej ocenie dziecko ma trudną sytuację w kontakcie z wymiarem sprawiedliwości i często jest ona przyczyną wtórnej wiktymizacji. Z tego powodu referentka postulowała o kształcenie umiejętności nawiązywania kontaktu z dzieckiem, ponieważ brak przygotowania i wiedzy w tym zakresie powoduje przestrzeń do procesów wtórnej wiktymizacji. W prezentacji Edukacja osadzonych w Zakładzie Karnym dla Młodocianych w Sucanach Ladislav Chlpik (Zakład Karny dla Młodocianych w Sucanach, Słowacja). Wskazał, jak ważny jest nacisk podczas odbywania kary na to, żeby osadzeni młodociani musieli samodzielnie podejmować działania, nie byli z nich wyręczani, ponieważ po opuszczeniu zakładu karnego nie będą potrafili działać i funkcjonować samodzielnie. Podsumowując swoje wystąpienie, podkreślił, że edukacja młodocianych daje perspektywy na lepsze życie po opuszczeniu Zakładu Karnego. Następnie głos zabrała mgr Joanna Sztuka z Katedry Profilaktyki Społecznej i Resocjalizacji Akademii Ignatianum w Krakowie. W referacie pt. Dialog motywujacy jako alternatywa dla modelu kar i nagród oraz skuteczne wsparcie $w$ procesie zmiany $w$ postepowaniu z nieletnimi i młodocianymi, opartym na badaniach własnych, omówiła fazy i elementy dialogu motywującego oraz zasady tworzące go, które powodują, że najważniejszy w nim jest ,język zmiany”. Przedstawiła program pilotażowy „Motywator”, który jest ukierunkowany na rozszerzanie kompetencji osadzonych w zakresie umiejętności samodzielnego rozwiązywania problemów i rozumienia potrzeb własnych i innych oraz rozwój kompeten- 
cji społecznych. Ostatnie wystąpienie w drugim dniu przedstawiła Alicja Satława-Janiec (psycholog w Zakładzie Poprawczym i Schronisku dla Nieletnich w Raciborzu). Dotyczyło ono Psychologicznych uwarunkowań adaptacji nieletnich do warunków zakładu poprawczego. Jak wykazała prelegentka, obserwowalnych jest pięć strategii zachowania się nieletnich w nowym środowisku, jakim jest zakład poprawczy. Najważniejszy w adaptacji — zdaniem prelegentki — jest sam początek, kiedy to nieletni trafia do izby przejściowej, jest to przestrzeń, która daje nadzieję na nawiązanie wspólnych relacji, nieodzownych w dalszym procesie oddziaływań. Zasadniczo wystąpienia i dyskusje w tym dniu konferencji koncentrowały się wokół najmłodszych uczestników procesu resocjalizacji. Kolejni referenci prezentowali swoje doświadczenia i aktywność, pokazując, że warto dołożyć wszelkich starań oraz trafnych diagnoz, aby w przyszłości ograniczyć liczbę osadzonych w zakładach karnych.

W ostatnim dniu konferencji odbył się panel poświęcony dobrym praktykom. Jego uczestnicy mogli zapoznać się z kompleksową działalnością podejmowaną przez praktyków na rzecz skutecznej readaptacji. Pierwszą część tego panelu otworzyła prezentacja Gdzie kończą się projekty, a zaczyna system? O rozwiazaniach Projektu Pro Domo w wymiarze nowych uwarunkowań, przygotowana przez Ewelinę Ćwiertnię kierownika Centrum Integracji Pro Domo w Krakowie. Przedstawiła ona etapy powstawania centrum, zwróciła uwagę na to, jak ważna jest praca $\mathrm{z}$ osadzonym przed opuszczeniem przez niego zakładu karnego i jak pomaga w tym prowadzony projekt „Konsultacje”. Zwróciła uwagę na opór społeczności lokalnej przed inicjatywą, jaką jest centrum. Postulowała, że takie centra intergacji powinny być włączone jako rozwiązania systemowe podobnie jak placówki opiekuńczo-wychowawcze. Kolejne wystąpienie pt. Stygmat bytego więźnia - sytuacja psychospołeczna osób opuszczajacych zakłady karne i sposoby pomocy im na podstawie doświadczeń Ośrodka Pomocy Postpenitencjarnej w Lublinie zaprezentowała Karolina Wychowaniak (koordynator Ośrodka Pomocy Postpenitencjarnej w Lublinie, Stowarzyszenie Centrum Wolontariatu w Lublinie). Podobnie jak jej przedmówczyni podkreśliła, że organizacje pozarządowe wypełniają lukę instytucjonalną w zakresie pomocy osobom opuszczającym zakłady karne. Przedstawiła realizowane projekty, które również są dużą pomocą dla byłych osadzonych. Referentka zagra- 
niczna dr Lenka Stefakova (Uniwersytet Katolicki w Rużomberku, Słowacja) podzieliła się informacją na temat wydawanego przez organizację pozarządową informatora „Co Dalej”, który pomaga byłym osadzonym w poruszaniu się na wolności w zakresie ich podstawowych potrzeb. Ukazuje się on corocznie w trzech językach: słowackim, węgierskim i romskim. Organizacja przygotowała interaktywną mapę, na której byli osadzeni mogą znaleźć wszystkie potrzebne instytucje. Z kolei referenci: Edward Szeliga (prezes Fundacji „Pomost” w Zabrzu, terapeuta uzależnień) oraz Piotr Wieczorkowski (specjalista Psychologii Klinicznej, specjalista Psychoterapii Uzależnień, Ośrodek Profilaktyki i Leczenia Uzależnień w Zabrzu) w wystąpieniu Wdrażanie innowacyjnych rozwiązań readaptacji - Employment Bridge to the Future od strony praktycznej przedstawili innowacyjne rozwiązania diagnozy resocjalizacyjnej. Zaprezentowali wypracowany model diagnozy, wskazując, że prawidłowe rozpoznanie jest kluczowym ogniwem w procesie readaptacji. Postulowali utworzenie zawodu specjalisty readaptacji. Drugą część panelu poświęconego dobrym praktykom rozpoczął kpt. Dawid Katolo z Zakładu Karnego w Tarnowie wystąpieniem pt. Oddziaływania penitencjarne wobec skazanych stwarzających poważne zagrożenie spoleczne albo poważne zagrożenie dla bezpieczeństwa zakładu $w$ kontekście ich readaptacji społecznej i przygotowania do życia po zwolnieniu. Referent wskazał na specyfikę oddziału i prowadzonych tam programów. Kolejny referat - Społeczeństwo obywatelskie i obok — należał do Erazma Humiennego (Stowarzyszenie Pomocy Ludzie Ludziom we Wrocławiu). Podobnie do przedmówców prelegent przedstawił problemy związane z inicjatywami mającymi na celu pomoc wykluczonym oraz ich akceptację przez społeczeństwo. Apelował o danie wykluczonym szansy i obalenie mitu niezrozumienia społecznego. Wojciech Kuźmicki (Sekretarz Rady, kierownik II Zespołu Kuratorskiej Służby Sądowej Wykonującego Orzeczenia w Sprawach Karnych, Sąd Rejonowy we Włocławku) w wystąpieniu pt. Kujawsko-Pomorska Rada Terenowa do Spraw Społecznej Readaptacji i Pomocy Skazanym - charakterystyka dotychczasowych działań na rzecz readaptacji skazanych na obszarze Województwa Kujawsko-Pomorskiego podał informacje, które ukazują działania rady oraz to, że warto podejmować współpracę instytucji biorących udział w procesie readaptacji. Ostatnie wystąpienie dotyczyło readaptacji skazanych 
kobiet na przykładzie Zakładu Karnego w Krakowie Nowej Hucie. Major Paweł Pomykalski (starszy wychowawca, Zakład Karny w Krakowie Nowej Hucie) przedstawił charakterystykę zakładu karnego oraz prowadzone w nim działania. Podkreślił, że duże znaczenie, oprócz programów resocjalizacyjnych, ma zatrudnienie i kształcenie osadzonych kobiet, a rozmowa z nimi jest podstawą wszelkich oddziaływań.

Podsumowując, należy stwierdzić, że ostatni panel konferencyjny pokazał uczestnikom mnogość inicjatyw realizowanych na szczeblu pozainstytucjonalnym i umożliwił zapoznanie się ze sprawdzonymi w praktyce sposobami skutecznej readaptacji społecznej.

Istotną zaletą tej i poprzednich konferencji było to, że pozwoliła ona na spotkanie przedstawicieli świata nauki z kraju i zagranicy, którzy zajmują się tematyką readaptacji społecznej, oraz z praktykami działającymi w tej dziedzinie. Umożliwiła ona wymianę poglądów i doświadczeń, w tym także zapoznanie się z rozwiązaniami i metodami pracy stosowanymi za granicą. Uczestnicy konferencji byli zgodni co do tego, że oddziaływania prowadzone w zakładach karnych, kontynuowane po opuszczeniu tych zakładów przez skazanych, prowadzą do skutecznej readaptacji społecznej. W trakcie dyskusji nad sposobami zwiększenia skuteczności tych działań zwrócono uwagę na potrzebę zapewnienia spójności wysiłków podejmowanych przez różne podmioty, stosowania wystandaryzowanych narzędzi, właściwego adresowania pomocy i motywowania skazanych do zmiany. Właściwa pomoc, jak stwierdzili uczestnicy tej konferencji, polega na trafnej diagnozie i poznaniu czynników, które miały wpływ na wejście w konflikt z prawem. Kolejne wspólne wnioski dotyczyły objęcia systemem podejmowanych inicjatyw w zakresie tworzenia ośrodków pomocy postpenitencjarnej. W celu dalszego doskonalenia umiejętności, poszerzania wiedzy, wzbogacania metod pracy i dzielenia się doświadczeniami planowana jest następna konferencja w 2019 roku. 